\title{
Marx's critical discourse for thinking about environmental devastation: a perspective beyond the hegemonic imaginaries of sustainability
}

El discurso crítico de Marx para pensar la devastación ambiental: Una perspectiva más allá de los imaginarios hegemónicos de la sostenibilidad

Josemanuel Luna-Nemecio

Autonomous University of Zacatecas - Mexico

Cuernavaca, Mexico

josmaluna2@gmail.com

\section{ABSTRACT}

The historical development of contemporary capitalism has produced an environmental crisis of global dimensions. The predominance of harmful capital technology determines the deployment of the capital productive forces that overexploit and pollute nature in ways never seen before. In this context, the present study aims to advance towards the reconstruction of the ecological streak of Marxism from Marx's critical discourse, distancing itself from both the hegemonic imaginaries of sustainability. An exploratory analysis of documents was followed to present the arguments that both Conventional Economics (CE) and environmental economics deploy to try to explain contemporary environmental devastation, and subsequently, from this impotent criticism and prey to the logic of the market and value as a social form, it goes on to structure the hegemonic imaginaries of sustainability. In this sense, this paper argues for the need for the critical and scientific discourse of Karl Marx to think about the environmental devastation and the objective conditions of possibility for ecological capitalism; thus, it was possible to address the ecological and political-libertarian dimension of Marx's thought and the task of developing it to break with the hegemonic views of sustainability; and overcome the series of misrepresentations and misstatements that have been made to an alleged anti-ecological view of Marx. The study concluded that, while the struggle for the environment has become somewhat urgent, this front does not replace that of the class struggle; that is, the contradiction between capital and nature does not subordinate to the contradiction between capital and labor but, on the contrary, updates it. Therefore, the validity of Marx's critical discourse is essential, in its genesis and development, to make an ecological criticism of the economics and politics of contemporary capitalism.

Keywords: criticism of the political economy; critical discourse; Marxism; sustainability. 


\section{RESUMEN}

El desarrollo histórico del capitalismo contemporáneo ha producido una crisis medioambiental de dimensiones globales. El predominio de la tecnología nociva del capital determina el despliegue de las fuerzas productivas del capital que sobreexplotan y contaminan la naturaleza en formas nunca vistas. En este contexto, el presente estudio pretende avanzar en la reconstrucción de la veta ecológica del Marxismo desde el discurso crítico de Marx, distanciándose de los dos imaginarios hegemónicos de la sostenibilidad. Se siguió un análisis exploratorio de documentos para presentar los argumentos que tanto la Economía Convencional (EC) como la economía ambiental despliegan para tratar de explicar la devastación ambiental contemporánea, y posteriormente, desde esta crítica impotente y presa de la lógica del mercado y del valor como forma social, se pasa a estructurar los imaginarios hegemónicos de la sostenibilidad. En este sentido, este trabajo argumenta la necesidad de que el discurso crítico y científico de Karl Marx piense en la devastación ambiental y en las condiciones objetivas de posibilidad del capitalismo ecológico; así, se pudo abordar la dimensión ecológica y político-libertaria del pensamiento de Marx y la tarea de desarrollarlo para romper con las visiones hegemónicas de la sustentabilidad; y superar la serie de tergiversaciones y descalificaciones que se han hecho a una supuesta visión antiecológica de Marx. El estudio concluye que, si bien la lucha por el medio ambiente se ha convertido en algo urgente, este frente no sustituye al de la lucha de clases; es decir, la contradicción entre el capital y la naturaleza no se subordina a la contradicción entre el capital y el trabajo sino que, por el contrario, la actualiza. Por lo tanto, la vigencia del discurso crítico de Marx es esencial, en su génesis y desarrollo, para hacer una crítica ecológica de la economía y la política del capitalismo contemporáneo.

Palabras clave: crítica de la economía política; discurso crítico; Marxismo; sostenibilidad.

\section{Introduction}

The 21st century has moved towards an increasingly complex complication of the current environmental crisis (Dai \& Zhang., 2009). The processes of production and consumption of energy, materials, and biomass that characterize the industrialization and urbanization of the territory have generated scenarios of overexploitation and pollution of nature. The degree of progress of this destruction of the natural conditions of possibility for social reproduction as a whole takes various measures and territorial and historical-temporal specificities, according to the degree of development of capitalism. Above all, it must be considered that the current environmental crisis has reached its globalization, while the capitalist market and big industry also have a planetary scale.

The development of contemporary capitalism is characterized by the expansion of certain types of capital productive forces that are environmentally destructive (Luna-Nemecio, 2020). Moreover, during neoliberalism, a process of capital accumulation has unfolded that is not based one-dimensionally on the dispossession of the social means of production. On the other hand, the process of capital accumulation that accompanies the global devastation process of nature is a residual and terminal type since it involves stripping the direct producers of the social media of procreative reproduction of humanity (Veraza, 2007). Therefore, the confluence of 
these processes that structure and characterize the formal and real subsumption of the work process have become real subsumption of consumption under capital (Veraza, 2009), ended up generating the conditions of possibility of an environmental emergency in those territories where the planetary automaton has been seated.

In this context of an ecological crisis characterized by the global devastation of the environment, it becomes necessary to carry out research that allows offering critical explanations about the genesis, structure, and development of this process. The degree of pollution and overexploitation of nature by the processes of configuration of industrial productive corridors, megaprojects, transport, and communication networks has driven the development of an academic vein of reflection on the current environmental crisis and on the ways to overcome it.

In this sense, various discourses and imaginaries have been configured on sustainability as a means to diagnose and propose ways out of the global environmental crisis (Arizmendi, 2005). However, this proposal has become a mainstream discourse of economic nature that preponderates the increase of capital before the conservation of nature. In this sense, most of the studies that take as an object of study the issue of the environmental crisis do it from this viewpoint that today hegemonizes the majority of institutional ecologist discourses.

On the other hand, as part of the counter-hegemonic discourses on sustainability, there has been a consolidation of viewpoints that from Conventional Economics (CE) (Astroulakis, 2013) or, from a Political Ecology (PE) (Treacy, 2020), seeks to elaborate a critical discourse on the processes of ecological devastation deployed by capital. However, these perspectives end up launching a nonspecific reflection on the node of the ecologic crisis by explaining it from the immediacy of common sense and establishing hasty and deterministic conclusions about the supposedly structural and immutable destruction of nature by capital.

The distraction, by the hegemonic and confrontational or critical imaginaries of sustainability, has been accompanied by a process of the crisis of Marxism (Veraza, 2015). The thinking of Karl Marx was called into question given the confusions and misrepresentations to which he was subjected both by Stalinian dogmatism, as well as by the bourgeois ideology itself that took pains to identify it with the process of capitalist development present in the USSR (MartínezBautista, 2018). Despite this network of attacks and confusions about Marx's critical discourse, reality itself has been responsible for evidencing the validity of the structural laws proposed by the revolutionary of Trier (Eagleton, 2018). This process realized the need to carry out what Jorge Veraza has conceptualized as a reconstruction of Marxism (Miranda, 2020). It has become necessary to put Karl Marx back on his feet once the Marxists of the nineteenth and twentieth centuries turned him on his head, by censoring him in a revisionist way, as Bersneint did (Reveco, 1991), fracturing him in the way Althusser did (Geymonat, 2015), pillaging him like Foucault (Pavón-Cuellar, 2020) or dogmatizing him in the manner of Stalin (Fuentes, 2020).

This recovery of Marx's thought involves removing from the middle the whole series of lies that have been given around what Karl Marx proposed. For this study, it becomes essential to reconstruct Marxism ecologically as a critical discourse that allows for a scientific explanation of the current environmental devastation. It must, therefore, be acknowledged that while Marx's idea, which does not touch on the ecological issue in his global critique of bourgeois 
society, has prevailed, this is not the case. The same happens in the alleged Promethean and Productivist perspective that Marx is attempting to attribute (Sheasby, 1999), and which attempts to present Marx as an accomplice of the capitalist environmental devastation, in particular.

In contrast, several Marxists seek to clarify this series of misrepresentations that serve to create the image of an anti-ecological Marx or one who is indifferent to environmental issues. However, these approaches from Marxism to the study of the ecological crisis have many shortcomings and gaps. Such is the case of the theoretical work of James O'Connor (2001), who takes stock of all the criticisms and the alleged lacks and misunderstandings that, according to him, Marx had concerning ecology. O'Connor tries to respond to the ecological challenge represented by environmental devastation from a Marxist perspective. Although, from the outset, he eliminates all those elements of Marxism that are not "useful" for the configuration of a "green" or ecological Marxism; for example, in O'Connor's analysis, the category of productive forces is erased, which is central for thinking about the ecological issue from Marx's thought (Veraza \& Barreda, 2018).

On the other hand, Elmar Altvater (2006) realizes a fundamental contribution to the critical thinking of ecology from a Marxist perspective. Altvater starts from the contradiction between the use-value and the value of trying to construct an ecological critique of the political economy (Altvater, 2005). In the analysis of this author, nodal concepts are not recovered within Marx's critical discourse. For instance, neither the productive forces nor the formal and real subsumption of the work process is addressed. However, Altvater's contribution in the formation of an ecological Marxism is to create dialects in Marx's law of value and his criticism of the environmental devastation produced by capital, in addition to the approaches that Polanyi (Block, 2003) and Georgescu-Roegen (2013) made about entropy from green economics.

One of the contributions to the formulation of a critical ecological theory is in Political Ecology. Which was formulated as a school of thought in which different paradigms converge that seek to explain the environmental degradation that is very close to the proposals made from ecological Marxism but without recognizing this contribution and, even calling it antiecological; still, since the explanation of the environmental crisis as a result of the corporate and state mismanagement of natural resources, it is criticized and denied that Karl Marx has had an ecological criticism of capitalist development. Political ecology has Joan Martínez Alier as one of its greatest exponents. He has elaborated, integrally, a critical review of each of the investigations that address the relationship between ecological and economic thought (Alier \& Jusmet, 2015), reaching the deterministic conclusion that capitalism is anti-ecological (PérezVega, 2020). Beyond these inaccuracies, Alier's contribution is that he manages to study the alternatives of environmental and economic management that are associated with resistance movements and the struggle against contemporary environmental devastation.

Faced with such theoretical perspectives that seek to think of the environmental devastation problem or, rather, environmental devastation as a problem, more powerful contributions are found to reconstruct the ecological streak of Marxism. First of all, there is John Bellamy Foster's (2000) work, which differs from others that attempt to think about environmental degradation from a Marxist perspective. Foster makes recovery of Marx's thought as the nucleus of a 
profound critique of the rupture of the metabolism of nature by capital. This author presents an orthodox-but not dogmatic - argument for the ecological dimension of Marx's critical discourse. The work process is Foster's starting point for the reconstruction of Marxism on the ecological side (Foster, 2017). However, his analysis fails to account for the processes of formal and real subsumption of the work process, nor does it recover the centrality of the concept of productive forces to make an ecological criticism of capitalist development.

Secondly, it is fundamental to recognize Jorge Veraza (2012) contribution to reconstructing ecological Marxism. His contribution is quadruple, because: a) he manages to develop Marxism to account for the specificity of contemporary capitalism, giving an account of the complication of the real subsumption of the work process until it becomes real subsumption of consumption (Veraza, 2009); (b) specifies that the processing of goods, and the realization of the surplus-value contained therein, is based on the production of harmful-use values; c) recovers the concept of productive forces differentiating them between those of a procreative nature and those of a technical nature, as well as concerning harmful capitalist technology, that is, it distinguishes between the capital productive forces and the productive forces of humanity. In addition, d) proposes the concept of residual and terminal original accumulation of capital (Veraza, 2007) to account for the specificity of the general law of capital accumulation proposed by Marx but beyond considering it as a simple mechanism of dispossession. All these contributions of reconstruction of Marxism as an ecological, critical, and communist discourse are concretized in the main contribution of Veraza to account for the specificity of contemporary capitalism under what this Mexican Marxist calls Capital as real subsumption of low consumption.

In the context of the debate within and outside Marxism on the ecological question, the present study seeks to address the following research problem: "Can Marx's critical discourse be taken as an approach to account for the environmental devastation produced by contemporary capitalism, while making it possible to raise a new socio-ecological perspective to think about sustainability?"

To address this problem, the objectives of this study are: 1) to present the central arguments that conventional economics raises to think about contemporary environmental devastation from the hegemonic imaginaries of sustainability; 2) to argue about the need for Karl Marx's critical and scientific discourse to think about environmental devastation and the objective conditions of possibility of ecological capitalism, and 3) to address the ecological and politicallibertarian dimension of Marx's thought and the task of developing it to break the hegemonic views of sustainability.

\section{Methodology}

Type of study

An exploratory analysis of documents was accomplished. Research, selection, systematization, synthesis, and critical analysis of documents were done based on the following criteria: select recent years of publication; determine the languages of publication; specify the type of publications that will be part of the literature reviewed. The analysis of the information was carried out with the procedure of thematic coding, the derivation of the categories of analysis from research questions. 
Searching information was focused on scientific articles published in journals indexed in Scopus, Redalyc, Scielo, and Web of Science. In addition, published research in academic books that are classic references around the subject of study was taken into account. These publications were reviewed and analyzed from critical reading and based on Marx's critical discourse contained in his critique of political economics.

\section{Study phases.}

The following study phases were followed for the approach and development of the research topic:

Phase 1. Searching for primary and secondary sources. Not only analysis of the academic literature was made on the environmental devastation and criticism of political economy subject, but also

Phase 2. Selection of sources relevant to the study. Sources were selected based on criteria of relevance, consistency, and practicality for their systematic approach.

Phase 3. The realization of documentary analysis considering the contributions of the revised bibliography and the generated experiences based on the principal thematic references.

Phase 4. Review and improvement from the consultation of peer experts in the field. The study was presented to experts in criticism of political economics and environmental devastation.

\section{Research findings}

\subsection{Conventional Economics as an expression of the hegemonic perspective of sustainability}

The environmental and ecological problems are evident from various perspectives within economic thought. However, the scientific approach that Conventional Economics (CE) has taken to analyze the environmental crisis has not been objective or free of a political bias. In this sense, when it comes to taking a panoramic and critical look at the way in which CE has tried to address the ecological crisis, we can find that marginalism has left this issue in oblivion (Altvater, 2005). Thus, so-called neoclassical economics not only throws overboard the theory of labor value as a foundation for explaining the economic dimension of society, but also erects a discourse of well-being from a consumerist perspective that ends up serving as an immaterial foundation for the hegemonic discourses of sustainability (Piña, 2005). CE presents sustainability as part of a consumerist hedonism that, in turn, characterizes the consumption of materials, energy, and biomass by capitalist society. Therefore, in the marginalist discourse, any kind of critical analysis of the objective and technical conditions of the production process is exempt. This includes lack of recognition of capitalist technique as the basis of the current environmental crisis.

CE proposes a theory of utility and consumer needs without recognizing the productive dimension of the economy or the issue of the use-value as an expression of human needs outside the consumerist perspective (Boltvinik, 2005). From this subjectivism, the notion of sustainability is founded as an alternative for the global ecological crisis focused on the 
appetites and desires for the environment's care by society. This perspective forgets the theory of the formal and real subsumption of the work process and does not recognize the process of real subsumption of consumption as the foundation of the development of contemporary capitalism, which translates into complete silence about the destruction of nature by the automatic system of machinery and great capitalist industry producing harmful use-values; and, therefore, denies recognizing the configuration of an ecological crisis such as the current one.

However, as the history of conventional economic thought developed, and the socioenvironmental consequences of the global ecological crisis became an increasingly impossible reality to hide, conventional economics was forced to elaborate the discourse of Environmental Economics (EE) as a means of explaining the relationship between capitalism and nature (Cavalcanti, 2018).

The EE raises notions such as "natural capital"; "ecological costs"; "environmental externalities" to try to address the devastation that capitalism makes of nature (Rodríguez \& Cubillos, 2012). However, this way of wanting to recognize how capitalist modernity has negative environmental effects ends up being an update of the oblivion of nature by the EE. Meanwhile, it is only assumed from the perspective of value, seen as a natural resource; at the same time, it denies its characterization as a living system capable of adapting and generating its changes to achieve its self-preservation (Berchin \& Andrade, 2020).

EE represents a way in which CE simulates developing an environmental discourse by assuming environmental devastation from categories such as "natural capital". This consideration of nature under the concrete social form of value also represents the quantization of biomass and its reduction to a stock of practical resources to the capital increase. Moreover, talking about the "ecological costs of growth" (Flores \& Sarandon, 2002), the EE simulates that economic growth can be carried out without the various capitals assuming their responsibility for devastating the environment. In this sense, the productive consumption of natural resources by capital is consensual, provided that a system of economic compensation established, from market logic, seeks to restore the environmental balance produced (Altvater \& Mahnkop, 2002).

The hegemonic imaginaries of sustainability have introduced this market logic of environmental devastation by subordinating nature and the ecological effects of modernity to a system of artificial price allocation, without recognizing the urgent need to question the destructive nature of the capital productive forces. In addition, from the perspective of the CE that is shown as EE, sustainability is presented by the hegemonic discourses of bourgeois ideology from a neo-Malthusian perspective, where the population is pointed out as responsible for destroying nature, becoming prey to its deepest desires to irrationally consume the large number of harmful values of use presented as mercantile satisfaction of needs.

Therefore, we can see how both within the imaginaries of sustainability and the economy, we need a critical and scientific discourse that allows us to elaborate an objective, technological, scientific, and ecological critique of capitalist development. Therefore, we can see how both within the imaginaries of sustainability and the economy, we need a critical and scientific discourse that allows us to elaborate an objective, technological, scientific, and ecological 
critique of capitalist development. Thus, in ecological and economic-hegemonic discourses, such as the Sustainable Development Goals (SDGs) and the EE, the issue of environmental devastation is assumed as reductionist when explained from market logic.

\subsection{The Historical Necessity of Marx's Critical and Ecological Discourse to Understand Environmental Devastation}

Marx's theoretical thought has a unique characteristic, namely, it's critical, scientific, and political specificity in that it reveals its aspirations, its notion of freedom, and the need to demonstrate the various mechanisms of exploitation that unfold as a correlate of the formal and real subsumption of the world by capital (Marx, 2001). The core of Marx's theory is the theory of the formal and real subsumption of the labor process by capital. The real subsumption of work by capital implies the subjugation that capitalism makes to the form of the work process, that is, it turns the production process into space for the production of surplus-value and the proletarianization of humanity. On the other hand, the real subsumption of the work process leads to the development of the instruments and means of production to give them a capitalist stamp. Later, as these two processes were at the center of capitalist development, the capitalist technology used for the exploitation of surplus-value, derived in a bride capitalist technology producing harmful use-values. This complication is known as the real subsumption of consumption by capital.

The totality of Marx's critical discourse focuses on the question of the conditions of possibility of capitalism as such. In this sense, it is necessary to recognize the need to recover and reconstruct Karl Marx's thought in its totality since its interpretation by various Marxists has ended up distorting, despoiling, and censoring it. Therefore, it becomes necessary to make a critique of the interior of twentieth-century Marxism to put Marx on his own feet, and rescue the argument generating global criticism of contemporary society; and, from there, to rebuild the ecological vein within Marxism from Marx's critical, scientific and communist thinking.

In this reconstruction of the ecological criticism deployed by Marx against capitalism, it is to take into account the series of hypostasis that bourgeois ideology performs trying to distort any scientific analysis of the contradictory relationship between capital and nature. Although it has been present so far in the concrete historical form of environmental devastation, this does not mean that this is a structural dimension of capitalism (Luna-Nemecio, 2020). Marx proposed a triple legal form structure to explain the genesis, development, and epochal overcoming of the capitalist mode of production. Thus, with the law of value, the general law of capital accumulation; and the law of the tendency of the rate of profit to decrease, Marx's critical discourse is positioned above bourgeois political economy and even more so than vulgar economists.

In Marx's rationale for the general laws of capitalism, a general law of environmental devastation by capital is not present as such. This "absence" is not due to any forgetfulness, plot leap, or disinterest of Marx in giving an account of the entire process of capital production throughout his critique of political economics. Instead, Marx is assuming that, while capital has deployed machinery and large industry overexploiting and polluting nature as part of the goods production process, and realized them in the nascent world market, it is because of a low degree of development of humanity's productive forces and their subordination to the 
concrete social and historical form of capitalist technology. Therefore, it cannot be a conditio sine qua non for the existence of capitalism as a mode of production, as it is the extraction of surplus-value, the subordination of the use-value to the value of the exchange or the original accumulation of capital.

In this way, it can be stated that there is a relationship between Marx's thought and the urgent need to carry out a critique of the devastation of nature that capitalism has produced to this day. Hence, to understand the conditions of possibility for something like a global ecological crisis to exist, Marx's critical discourse is needed. The use of reconstructing the ecological streak of Marxism is not only to establish a critique of the capitalist mode of production and the harmful capitalist technology that today predominates as part of the techno-scientific body required for the exploitation of surplus-value to humanity. But, also, to rescue the ecological, political-libertarian (communist), and the scientific dimension of Marx's critical discourse regarding the series of interpretations that, under the pretext of wanting to develop it, have ended up validating both the hegemonic and neo-Malthusian imaginaries of sustainability in the 2030 Agenda, as well as deterministically denying any possibility of ecological reconfiguration of capital and its mechanisms of formal and real subsumption of processes of work and consumption.

\subsection{Towards a critique of the political economy of environmental devastation, or the ecological dimension of Marx's thought and the task of its development}

Marx's critical discourse aims to study the search for the historical specificity of capitalism. Therefore, it has an epistemic commitment to the search for truth and the criticism for every ideology. Karl Marx's thought is, then, a theoretical weapon with the sense of serving humanity to fight against capitalism on multiple fronts. Accordingly, Marx's critical discourse (Echeverria, 1986) is used to demonstrate the physical and psychological-emotional domination of which humanity is currently subject in capitalism. From this political-libertarian function of scientifically exposing the truth of capitalism, it becomes necessary to realize the use of being able to make an ecological critique of the mechanisms of formal and real subsumption of the work process and consumption that contemporary capitalism deploys to continue exploiting surplus-value.

The capitalist mode of production is presented by Marx as a concrete historical system of social reproduction based on widespread exploitation. Faced with this materially determined fact, humanity today has been proletarianized, and has the possibility of liberating itself, of acting to build various paths that lead them to reconquer their freedom. In ecological terms, knowing the truth regarding the relationship between humanity and nature in the concrete historical context of capitalism starts from leading Marx's thought towards its contrast with contemporary environmental devastation. In order to carry out this task, it is necessary to study and understand the book "Capital" and to develop the series of clues, notes, or ideas that Marx left throughout his work for the writing of the five remaining books of the general plan of Critique of Political Economy. Only in this way can we access all the revolutionary critical, scientific, and political potential of the global critique of bourgeois society designed by Karl Marx, including his radical criticism of the development of the capital productive forces and the socio-environmental devastation they generate, not as a conditio sine qua non for the 
accumulation of capital, but as an expression of a certain inadequacy between the social form and the natural form of social reproduction within capitalism.

In this regard, starting from Marx and not from the Marxism or Marxists who tried unsuccessfully to develop it throughout the 2oth century, will make it possible to rescue the political sense of evidencing the truth regarding the anti-ecological character of capitalism. Thus, it will also possibly construct a theory that is free of any ideological content and in which this search for truth is existing because only in this way could both the criticism of political economy and historical materialism in Marx's thought be taken as a political theoretical weapon that would allow society to progress differently before reality.

This awareness, materially produced, will make it possible to create certain conditions for humanity to understand the specifics of the socio-environmental devastation generated by the current status of the techno-energetic pattern of capitalism and to deploy a radical criticism of capital, beyond looks disenchanted with the technique or, paradoxically, that assume technological views. Nonetheless, above all, it will allow us to argue with the hegemonic imaginaries of sustainability present in the 2030 Agenda, while these oscillate between explanations and solutions to environmental devastation either from a neo-Malthusian perspective or from the degrowth. The Sustainable Development Goals, as the center of the 2030 Agenda, has contributed to eco-fascist discourses that structure various public policies of conservative and progressive governments today, whether in the United States or the rest of the American continent, Asia and Europe.

The task of Marxism and Marxists in the 21st century is to study, understand and develop Marx's thought to reconstruct its ecological side. This development will not be carried out by the ruling class, but is a task to be performed by those who need Marxism as a political and eco-libertarian weapon. In this respect, those called modern, in the form of a proletarianized humanity, have the historical responsibility to develop the thought of Karl Marx in order to confront capital; and thus, be able to set the wheel of history on the track and get the train of social development back on track in a community and libertarian sense in terms of social and environmental justice.

The task of reconstructing the ecological streak within Marxism, starting with Marx, involves criticizing the series of stratagems that immediately, mediate or absolute, have sought to hide the great contribution that it made within economic science. This German thinker not only managed to account for the specificity of the surplus value as a sustenance of capitalism's development and, from there, to build his global critique of bourgeois society; in addition, Marx established the argumental and scientific basis to be able to launch a critique of the devastation that the concrete historical form of capital makes to nature. In this sense, Karl Marx can be defined as one of the most radical critics of the environmental crisis produced by the predominance of capitalist technology as the core of productive forces.

The strategies that bourgeois society itself has devised to silence or misrepresent Marx's critical discourse attempt to overshadow, devalue, or deny the ecological ingredient of its critique of political economy. Moreover, the bourgeois class itself seeks to present, without any basis, a Marx in favor of environmental devastation. From there, his thinking is undermined by wanting to show him as a "prisoner" in the myth of progress and with a Promethean look 
at the scientific and technological development of modernity. That is, not recognizing Marx's criticism of harmful capitalist technology and the capital productive forces; when, in fact, we can find in Karl Marx the arguments and decisive points to carry out a critical history of technology, and from there recover the historical sense of the development of the productive forces of humanity.

\section{Conclusions}

The ideological discourse, in favor of the economic and power relations that unfold in a capitalist society, tries to delegitimize or deny the active role that Marx had in the construction of a global critique of capitalist modernity. In this sense, faced with the emergence of a generalized devaluation of capital and the ecological devastation of the planet, we have that Marx's critical speech becomes a crucial element to carry out a counter to the current civilizational crisis, which we euphemistically refer to as neoliberalism.

Given such a catastrophic scenario, it is urgent to carry out a reconstruction of Marxism as a whole. Additionally, as argued in the present study, it is extremely important to carry out a reconstruction of the ecological streak within Marxism from the ontological and epistemological concepts and foundations originally proposed by Marx.

The main axis of this paper is a "call to arms" or rather to pens, to be written about the ecological critique of capital; that is to say, a call for more authors to get involved in the thought of ecological Marxism. This paper suggested leaving aside the dogmatic readings of the contributions of the most important ecological Marxists of our time and focus on the critical discourse of Marx.

In this sense, it is necessary to recognize the common point that remains in the construction of an ecological Marxism and its ecosocialist proposal existing both in O'Connor, Altvater, and Foster himself. For these authors, the capital-nature contradiction becomes a fundamental distinction in capitalism. Therefore, these interpretations end up displacing in a second term, the capital-labor contradiction as an essential part of capitalism; and, therefore, end up being a misrepresentation of Marx's critical discourse.

At the same time, this confusion on the part of eco-Marxism does not recover the concepts of formal and real subsumption of the work process, which are nodal for thinking about the development of capitalism since Marx. The same goes for the concept of productive forces, which has been forgotten as a central dimension for developing Marxism towards an ecological critique of capitalism. Moreover, it raises confusion in which all technological development is assumed as environmentally destructive, as Marcusse (1987) did by confusing capitalist technology with harmful capitalist technology and, since this confusion, not recognizing the distinction between the capital productive forces and the productive forces of humanity.

Contrary to the CE, Marx's critical discourse realizes that the understanding of ecological devastation of the planet by the capital productive forces cannot be done from closed 
disciplinary frameworks. In this respect, for Marxism, it is necessary to enter communication between various disciplines due to the complex relationship of nature with the historicalconcrete forms of historical reproduction of society. In such a way, from this theoretical perspective, it is advocated for multidisciplinary knowledge that starts from Marxism as the articulating axis of criticism, both of the environmental devastation produced by capital, as well as of the hegemonic discourses of sustainability present in the 2030 Agenda and that today subordinate and silence the socio-ecological movements of masses that seek to reform, still, revolutionize capitalism to transcend it from a counter-hegemonic left.

In this sense, it is strategic to take to the masses the ecological and critical communist discourse of Karl Marx. Therefore, the study of Marxism is necessary for the construction of post-industrial solutions that allow progress towards good living and full sustainability.

However, it is supremely urgent to break with the ideological traps of the CE, which tries in the form of the EE and the hegemonic discourses of the 2030 Agenda to subordinate the ecological fight in favor of socio-environmental justice, under interests related to increasing capital and exploitation of surplus-value. That involves questioning the sustainability strategies exposed in the SDGs but, at the same time, not deterministically canceling the historical possibility of capitalism to metamorphose itself and deploy a process of real subsumption of the process of capital's work and accumulation of value that does not exceed the ecological peaks of the planet. Thus, not every increase of capital is based on dispossession, nor is all dispossession for the valorization of value. In addition, the extraction of relative and absolute surplus-value to the proletarian class does not require per se the devastation of nature because - although today it is unlikely given the advance of the global ecological crisis and the cynicism of the bourgeoisie - the productive consumption of nature under capital could pursue a different streak to the overexploitation and pollution of the environment. It does not exempt the possibility that this care of nature will be subordinated to the value-form, and, therefore, it will be converted into a capitalist mercantile use-value.

Given the current time in which multiple crises (economic, environmental, cultural, democratic, and health, to say the most visible) converge, humanity has before it the urgent need to make a common front of struggle to get out of this civilizing degradation. It happens in the case of the social fighting for a dignified environment when not taking this objective as the ultimate goal of an anti-capitalist mass movement. However, the fight against environmental injustices on the part of capital must start, articulate and underpin the fight against the mechanisms of exploitation of surplus value. Hence, despite the seriousness of the global ecological crisis, the core of the aforementioned civilizing crisis is the contradiction between capital and the proletariat within the production process.

Due to all that has been mentioned in the present study, it was possible to make a plot presentation on the general approaches with which the CE tries to "criticize" the contemporary environmental devastation. This closed and infertile criticism made from the EE to the destruction of nature by capital ends up commodifying both nature and the socio-ecological damages generated by the development of the environmentally destructive capital productive forces. Additionally, this research presented the need for Karl Marx's critical and scientific discourse to think about environmental devastation and the objective conditions concerning the criticism about the 
ecology and the political economy of capitalism. Finally, this study addressed the ecological and political-libertarian dimension of Marx's thought and the task of developing it in order to break the hegemonic views of sustainability, and not only to recognize the possibility of an ecological reconfiguration of capitalism but also to demonstrate the importance of carrying out a fight against the mechanisms of overexploitation and pollution of nature by capital as a means of promoting criticism of the social relations of production that today continue to drive a class struggle between bourgeois and proletarian.

The pending tasks of this research are: 1) To carry out a timely analysis of Capital. Critique of Political Economy by Marx, to have on hand the textual quotations where he raises the bases for a reconstruction of the ecological streak of his thought and the criticism of the antiecological character of contemporary capitalism. 2) Criticize each of the 17 SDGs punctually and generally, in such a way that both its historical expiration is evident, as well as its function in maintaining the status quo of the productive forces and the social relations of production, which ends up making it impossible to build sustainable development, even within capitalism itself.

\section{REFERENCES}

Alier, J. M., \& Jusmet, J. R. (2015). Economía ecológica y política ambiental. Fondo de Cultura económica.

Altvater, E. (2006). ¿Existe un Marxismo ecológico? En, A. Borón, J. \& J. González. (Comp.) Teoría Marxista Hoy. Problemas y perspectivas (pp. 341-363). CLACSO.

Altvater, E. (2005). Hacia una crítica ecológica de la economía política (Primera Parte) (Fundamentos y Debate). Mundo Siglo XXI, 9-27. http://hdl.handle.net/10469/7415

Arizmendi, L. (2005). La crisis ambiental mundializada en el siglo XXI y sus disyuntivas. Revista Mundo Siglo XXI, (3), 17-36. https://doi.org/10.2307/j.ctvr7fcmg

Astroulakis, N. (2013). Desafiando a la economía convencional: un paradigma ético del desarrollo. Problemas del desarrollo, 44(175), 33-53. https://doi.org/10.1016/S0301-7036(13)71901-1

Berchin, I. I., \& de Andrade, J. B. S. O. (2020). GAIA 3.0: Effects of the coronavirus disease 2019 (COVID-19) outbreak on sustainable development and future perspectives. Research in Globalization, 2, 100014. https://doi.org/10.1016/j.resglo.2020.100014

Block, F. (2003). Karl Polanyi and the writing of the Great Transformation. Theory and society, 32(3), 275306. https://doi.org/10.1023/A:1024420102334

Boltvinik, J. (2005). El Rechazo al Concepto de Necesidades Humanas. Mundo Siglo XXI, (3), 37-57.

Cavalcanti, C. (2018). De la Economía Convencional a la Economía Ecológica: el significado de Nicholas Georgescu-Roegen y la Encíclica Laudato Si'del Papa Francisco. Gestión y Ambiente, 21(1supl), 49-56. https://doi.org/10.15446/ga.v21n1supl.75741

Dai, S., \& Zhang, W. (2020). Knowledge map of environmental crisis management based on keywords network and co-word analysis, 2005-2018. Journal of Cleaner Production, 262, 121168. https://doi. org/10.1016/j.jclepro.2020.121168

Eagleton, T. (2018). Why Marx was right. Yale University Press.

Echeverría, B. (1986). El discurso crítico de Marx. Ediciones Era

Flores, C. C., \& Sarandon, S. J. (2002). ¿Racionalidad económica versus sustentabilidad ecológica? Revista de la Facultad de Agronomía, 105. 52-67. http://sedici.unlp.edu.ar/handle/10915/15669 
Foster, J. B. (2000). Marx's ecology: Materialism and nature. NYU Press.

Foster, J. B. (2017). Marxismo y ecología: fuentes comunes de una gran transición. Contraste Regional,5(9), 87-101. http://revistacontrasteregional.ciisder.mx/index.php/rcr/article/view/15

Fuentes, D. (2020). El Marxismo: una evaluación de la crítica y el discurso ante la caída del Muro de Berlín. Revista mexicana de ciencias políticas y sociales, 65(238), 209-220. https://doi.org/10.22201/ fcpys.2448492xe.2020.238.71985

Georgescu-Roegen, N. (2013). The entropy law and the economic process. Harvard university press.

Geymonat, J. (2016). El problema de la ruptura teórica en Marx. Un balance de la tesis Althusseriana. Psicología, Conocimiento y Sociedad, 6 (1), 207-225. https://www.redalyc.org/ journal/4758/475848615010/475848615010.pdf

Luna-Nemecio, J. (2020). Neoliberalismo y devastación ambiental: de los límites planetarios a la sustentabilidad como posibilidad histórica. Resistencias. Revista de Filosofía de la Historia, 1(2), 89107. https://doi.org/10.46652/resistances.v1i2.24

Marcuse, H. (1987). El hombre unidimensional. Barcelona: Ariel.

Martínez Bautista, J. V. (2018). Marxist theses for the critique of the nature of the Russian Revolution of 1917 and the USSR. Religación. Revista De Ciencias Sociales Y Humanidades, 3(11), 38-47. http://revista. religacion.com/index.php/religacion/article/view/162

Marx, K. (2001). El capital. Libro I, capítulo VI (inédito): Resultados inmediatos del proceso de producción (Vol. 1). Siglo XXI.

Miranda, D. V. (2020). El Marxismo de Jorge Veraza como una reconstrucción crítica de la teoría marxista. Revista Disertaciones, 9(2), 37-57. https://doi.org/10.33975/disuq.volgn2.389

Pérez-Vega, I. (2020). El “desarrollo sostenible” es un engaño, aseguró Joan Martínez Alier. 44 Noticias. https://bit.ly/34jeZwb

Reveco, J. M. (1991). El revisionismo de Eduard Bernstein. Política. Revista de Ciencia Política, (28), 99-116. https://revistadematematicas.uchile.cl/index.php/RP/article/download/54464/57258

Treacy, M. (2020). La ecología política y el Marxismo ecológico como enfoques críticos a la relación entre desarrollo económico y medio ambiente. Revista colombiana de sociología, 43(2), 241-266. https://doi. org/10.15446/rcs.v43n2.77548

O’Connor, J. R. (2001). Causas naturales: ensayos de Marxismo ecológico. Siglo XXI.

Pavón-Cuéllar, D. (2020). Michel Foucault, su inconfesado Marxismo y su crítica de la psicología. Athenea Digital. Revista de pensamiento e investigación social, 20(1), 2229. https://doi.org/10.5565/rev/ athenea.2229

Piña, E. (2005). El Desarrollo Sustentable: Aportaciones de la escuela austriaca de economía. Estudios Sociales. Revista de Alimentación Contemporánea y Desarrollo Regional, 13(25), 142-161. http://www. redalyc.org/articulo.oa?id $=41702505$

Rodríguez, P. C., \& Cubillos, A. (2012). Elementos para la valoración integral de los recursos naturales: un puente entre la economía ambiental y la economía ecológica. Gestión y Ambiente, 15(1), 77-90. https://revistas.unal.edu.co/index.php/gestion/article/view/30819

Sheasby, W. (1999). Anti-Prometheus, post-Marx: The real and the myth in green theory. Organization \& Environment, 12(1), 5-44. https://doi.org/10.1177/1086026699121001

Veraza, J. (2007). Economía y política del agua. El agua que te vendo primero te la robé. Itaca.

Veraza, J. (2009). Subsunción real del consumo bajo el capital. Dominación fisiológica y psicológica de la humanidad. Itaca.

Veraza, J. (2012). Karl Marx y la técnica desde la perspectiva de la vida. Para una teoría marxista de las fuerzas productivas. Itaca. 
Veraza, J. (2015). Dialéctica histórica de la superación de la crisis del Marxismo: evidencia apodíctica y condiciones de posibilidad. Pensar desde abajo, (4), 201-271. https://dialnet.unirioja.es/servlet/ articulo?codigo $=5316424$

Veraza, J., \& Barreda, A. (2018). Teoría del valor, fuerzas productivas y la perspectiva humanista de Marx respecto a la naturaleza. Discusion en torno al articulo "Karl Marx: Naturaleza y critica de la economia politica”. Religación. Revista de Ciencias Sociales y Humanidades, 3(11), 151-158. http://revista. religacion.com/index.php/religacion/article/view/174

\section{AUTHOR}

Josemanuel Luna-Nemecio. Postdoctoral fellow at the Academic Unit in Development Studies, Autonomous University of Zacatecas, Mexico

\section{Conflict of interest}

The author declares that he has no conflict of interests.

\section{Contribution of the author}

Luna-Nemecio, J. conceived the original idea, carried out the bibliographic searching, and elaborated the first draft and final version of the manuscript.

\section{Acknowledgements}

This study is part of the activities of the postdoctoral fellow at the Academic Unit in Development Studies of the Autonomous University of Zacatecas, within the framework of the project "Socioenvironmental conflicts of water cut in the state of Morelos: a territorial analysis on the defense of water before the urban-industrial development promoted by the Morelos Integral Project". I thank

Dr. Darcy Tetreault for the review and improvement comments of this writing, as well as for the tutoring that he does of the postdoctoral project referred to. I also acknowledge the National Council of Science and Technology of Mexico (CONACYT) for the funding of this research through the

Postdoctoral fellowships for Mexico. 